\title{
Amadeus
}

International Multidisciplinary Journal IISSN 2525-3281

DOI: 10.14295/aimj.v4i7.89

\section{Physicians are at a higher risk than the General Population for Suicide?}

Izadora de Sousa Pereiral, Amanda Plácido da Silva Macêdo ${ }^{1}$ Ivna Celli Assunção de Sál; Larissa Melo Moreiral, Modesto Leite Rolim Neto

\begin{abstract}
Suicide is a huge public health problem, which needs more attention. One doctor commits suicide in the U.S. every day -- the highest suicide rate of any profession. According to the American Foundation for Suicide Prevention, physicians are at a higher risk than the general population for suicide. Methods: A Brief Communication that focus on the starkest sign of the crisis gripping medicine: the number of physicians who commit suicide every year. Include: discovery or development of new information's, novelty in modeling scientific, elucidation of mechanisms editorials and channels of information. Results: The medical profession has proven to have one of the highest risks of death by suicide among professions. About $15-30 \%$ of students and residents screen positive for depression. Studies also show that 1 in 16 trainees report suicidal ideation. The researchers also suggest that psychiatry help is still a taboo among doctors. Limitations: As Short Communications are expected to have higher than average impact on the field rather than report on incremental research, they will receive prioritized and rapid publication. Conclusion: Strategies to reduce preventable deaths should include preventive and treatment service. We should all strive to help usher in a new era of medical culture that promotes sustainable medical careers. Excessive pressures and expectations at work, may entail to a loss of meaning of work and of self for physicians.
\end{abstract}

Key-words: Suicide; Doctors; Medicine; Mental Health

\footnotetext{
${ }^{1}$ Faculty of Medicine, Federal University of Cariri (UFCA), Ceará, Brazil. Corresponding author: modestorolim@yahoo.com.br.
} 


\section{Médicos estão em maior risco do que a População Geral para o Suicídio?}

\begin{abstract}
Resumo: O suicídio é um enorme problema de saúde pública, que precisa de mais atenção. Um médico comete suicídio nos EUA todos os dias - a maior taxa de suicídio de qualquer profissão. Segundo a Fundação Americana para Prevenção do Suicídio, os médicos correm um risco maior do que a população em geral por suicídio. Métodos: Uma comunicação breve que foca no sinal mais marcante da medicina envolvente da crise: o número de médicos que se suicidam todos os anos. Inclua: descoberta ou desenvolvimento de novas informações, novidade na modelagem científica, elucidação de mecanismos editoriais e canais de informação. Resultados: A profissão médica provou ter um dos maiores riscos de morte por suicídio entre as profissões. Cerca de 15 a $30 \%$ dos estudantes e residentes são positivos para depressão. Estudos também mostram que $1 \mathrm{em}$ cada 16 estagiários relatam ideação suicida. Os pesquisadores também sugerem que a ajuda da psiquiatria ainda é um tabu entre os médicos. Limitações: Como é esperado que as comunicações curtas tenham um impacto acima da média no campo, em vez de reportar pesquisas incrementais, elas receberão uma publicação priorizada e rápida. Conclusão: As estratégias para reduzir as mortes evitáveis devem incluir serviços de prevenção e tratamento. Todos devemos nos esforçar para ajudar a inaugurar uma nova era da cultura médica que promova carreiras médicas sustentáveis. Pressões e expectativas excessivas no trabalho podem acarretar uma perda do significado do trabalho e do eu para os médicos.
\end{abstract}

Palavras-chave: Suicídio; Médicos; Remédio; Saúde mental.

\section{Introduction}

Suicide is the only cause of death that is higher in physicians than in nonphysicians. Not only are male physicians 40 per cent more likely that non-physicians to attempt self-harm, but the risk among female physicians has more than doubled as well. In the U.S., there are estimates that approximately 400 doctors die in this manner in the United States each year. That's roughly the equivalent to an entire medical school freshman through senior year (CBC Radio, 2019).

One doctor commits suicide in the U.S. every day -- the highest suicide rate of any profession. And the number of doctor suicides -- 28 to 40 per 100,000 -- is more than twice that of the general population. The rate in the general population is 12.3 per 100,000 (WebMD,2018).

According to the American Foundation for Suicide Prevention, physicians are at a higher risk than the general population for suicide. Because of long hours, high patient 
volume, academic demands, work compression, and irrational systems that negatively impact both patients and providers (Refinery, 2018). Medical practitioners are at high risk of depression and suicide. This risk may be greater in female medical practitioners, younger doctors and students, who also report higher rates of stress and burnout. The risk of depression and suicide is exacerbated by ready access to lethal means of suicide and low rates of help-seeking in this population (Bailey, Robison and McGorry, 2018).

The starkest sign of the crisis gripping medicine is the number of physicians who commit suicide every year - 300 to 400 , about the size of three average medical school classes. Male doctors are 1.4 times more likely to kill themselves than men in the general population; female physicians, 2.3 times more likely. The grim tally is probably an undercount, since many suicides aren't listed as such on death certificates. And it doesn't include suicides among medical students, which aren't tracked systematically in the United States (Stat, 2016). We need to talk about this in scientific, political and human terms, so we can find ways to improve care and treatment. Suicide is a huge public health problem, which needs more attention. Psychiatry needs to reach these people, before they get to that point (Linkoping University, 2018).

Over the last few years, suicides among U.S. doctors have stirred national discussion. In leading academic journals mental health experts have sought to address suicides among physicians and medical trainees. Media outlets have added coverage with headlines like "Why Do Doctors Commit Suicide?" and “The Hidden Epidemic of Doctor Suicides." Although suicide was one of the leading causes of death among residents, the rates of suicide for residents appeared to be much lower compared with the general population. For people aged 25 to 34, when doctors are commonly in residency training, the odds of suicide among residents were about one fourth that of their age-matched peers. The "surprising, are higher rates of depression in medical students... and the higher rates of suicide deaths in practicing physicians" compared with the broader public (Scientific American, 2017).

Understanding that there is a problem is the first step towards fixing it. It isn't easy for doctors to admit that they need help with their mental health. Doctors are too shy/scared to accept that they themselves have to seek help, especially for issues relating to mental health (The Windu, 2018).

Very often neglected, it is extremely crucial to look into the mental health scenario of those who look after us. The medical profession has proven to have one of the highest 
risks of death by suicide among professions. About $15-30 \%$ of students and residents screen positive for depression. Studies also show that 1 in 16 trainees report suicidal ideation.The most common mental illnesses among doctors happen to be affective disorders like depression and bipolar disorder, alcoholism and substance abuse and the most common method of suicide is the use of firearm or lethal medication overdose (The Better India, 2018).

As physicians we need to engage in self-care strategies. Healthcare organizations and employers also need to look at what in the work environment is modifiable.This also includes a change in the culture of medical education, with long-reaching effects on the entire system. Patients are receiving care from physicians and medical students who've been traumatized by their training,and have not been allowed to seek help without serious repercussions to their careers (Healthline, 2016).

The researchers also suggest that psychiatry help is still a taboo among doctors. There is need for equipping medical professionals with skills of stress management and mitigate stigma associated with mental disorders so that at the time of the need, the professionals can seek help (The Tribune, 2018).

Mental health is the foundation of life, and we've got to do everything we can to preserve it (CNN, 2018). Why physicians and health-care workers are more likely to complete suicide is unknown. It perhaps has to do with a work-related mental health syndrome called disengagement and burnout, which has reached epidemic proportions in health-care providers and nurses. Excessive pressures and expectations at work, paired with seemingly unattainable goals for quality and productivity as well as societal loss of trust in physicians, has led to a loss of meaning of work and of self for physicians (The Hill, 2018).

We should all strive to help usher in a new era of medical culture that promotes sustainable medical careers. In addition to monitoring our trainees (and colleagues) for signs of depression or burnout (Mayo Clinic, 2016), we need to set an example for them. This includes living a balanced lifestyle, utilizing appropriate teaching methods, and making our personal health a priority (Association for Academic Surgery- AAS. 2017).

Strategies to reduce preventable deaths should include preventive and treatment services, emergency support for trainees in distress, and ongoing monitoring and provision of wellness services that take into account the level of training, age of the trainee, and the 
time of year. Future research should explore institution- and program-level approaches to increase and support help-seeking behaviors by trainees in distress (Yaghmour et al. 2017).

Suicide, therefore, is an individual tragedy underpinned by unique personal issues and circumstances. However, it is well established that the rate of suicide in the medical profession is significantly higher than the general population and is one of the highest of any professional occupation (The medical Independent, 2019).

\section{Highlights}

Suicide is a huge public health problem, which needs more attention.

One doctor commits suicide in the U.S. every day -- the highest suicide rate of any profession.

About 15-30\% of students and residents screen positive for depression.

Strategies to reduce preventable deaths should include preventive and treatment service.

We should all strive to help usher in a new era of medical culture that promotes sustainable medical careers.

\section{Acknowledgements}

The authors' thank Research Group: Suicidology-Federal University of Ceará UFC and National Council for Scientific and Technological Development-CNPq - body linked to the Ministry of Science, Technology and Scientific Writing Lab, Medicine School - Federal University of Cariri - UFCA

\section{Role of the funding source}

Research Group: Suicidology-Federal University of Ceará - UFC / National Council for Scientific and Technological Development-CNPq - body linked to the Ministry of Science, Technology and Innovation to encourage research in Brazil. 


\section{Conflict of interests}

The authors declare that they have no competing interests.

\section{References}

CBC Radio (2019). Health professionals face an increased risk of suicide. Let's confront it. Retrieved from: https://www.cbc.ca/radio/whitecoat/blog/health-professionals-face-anincreased-risk-of-suicide-let-s-confront-it-1.5123935

WebMD. (2018). Doctors' Suicide Rate Highest of Any Profession. Retrieved from: https://www.webmd.com/mental-health/news/20180508/doctors-suicide-rate-highest-ofany-profession\#1

Refinery. (2018). YU Medical Student, Resident Die By Suicide Within Days Of Each Other. Retrieved from: https://www.refinery29.com/2018/05/198536/nyu-hospital-doctormedical-student-suicides

Bailey,E., Robinson, J., McGorry, P. (2018). Depression and suicide among medical practitioners in Australia. ternal Medicine Journal; 48: 254-258. Retrieved from: https://onlinelibrary.wiley.com/doi/pdf/10.1111/imj.13717

Stat. (2016). Why are doctors plagued by depression and suicide? A crisis comes into focus. Retrieved from: https://www.statnews.com/2016/07/21/depression-suicidephysicians/

Linkoping University. (2018). Honorary doctors put spotlight on depression and suicide. Retrieved from: https://liu.se/en/news-item/hedersdoktorer-lyfter-fragan-om-depressionoch-sjalvmord

Scientific American. (2017). Suicide Is Much Too Common among U.S. Physicians.

Retrieved from: https://blogs.scientificamerican.com/observations/suicide-is-much-toocommon-among-u-s-physicians/

The Windu. (2018). Suicide among doctors a public health crisis, says IMA. Retrieved from:https://www.thehindu.com/news/cities/Delhi/suicide-among-doctors-a-public-health-crisissays-ima/article23396037.ece

The Better India. (2018). Thev cure Us. But who can save them?We need to talk about doctor suicides. Retrieved from: https://www.thebetterindia.com/133293/suicide-amongdoctors-it-is-more-common-than-you-can-believe/

Healthline. (2016). Why Do So Many Doctors Die by Suicide? Retrieved from: https://www.healthline.com/health-news/so-many-doctors-die-by-suicide\#1 
The Tribune. (2018). 30\% doctors depressed, 17\% contemplated suicide. Retrieved from: https://www.tribuneindia.com/news/chandigarh/30-doctors-depressed-17-contemplatedsuicide/568459.html

CNN. (2018). Doctor: Suicide prevention: here's how you can help. . Retrieved from: https://edition.cnn.com/2018/06/08/opinions/suicide-prevention-you-can-helpvox/index.html

The Hill. (2018). American health-care workers are committing suicide in unprecedented numbers. Retrieved from: http://thehill.com/opinion/healthcare/389999-american-healthcare-workers-are-committing-suicide-in-unprecedented

Mayo clinic. (2016). Make the Difference: Preventing Medical Trainee Suicide. Retrieved from: https://www.youtube.com/watch?v=I9GRxF9qEBA

Association for Academic Surgery- AAS. (2017). Medicine's Ugly Secret: The Epidemic of Physician and Medical Student Suicide. Retrieved from: http://www.aasurg.org/blog/medicines-ugly-secret-epidemic-physician-medical-studentsuicide/

Yaghmour, N, A., Brigham, T. P., Richter, T., Miller, R. S., Philibert, I., Baldwin, D. C. Jr., Nasca, T. J. (2017). Causes of Death of Residents in ACGME-Accredited Programs 2000 Through 2014: Implications for the Learning Environment. Academic Medicine; 92 (7): 976-983. Retrieved from: https://journals.lww.com/academicmedicine/Fulltext/2017/07000/Causes_of_Death_of_Re sidents_in_ACGME_Accredited.41.aspx

The Medical independent (2019). The growing problem of suicide in the medical profession. Retrieved from: https://www.medicalindependent.ie/the-growing-problem-ofsuicide-in-the-medical-profession/

\section{How to cite this article (APA format):}

Pereira, Izadora de Sousa; Macêdo, Amanda Plácido da Silva; Sá, Ivna Celli Assunção de; Moreira, Larissa Melo; Rolim Neto, Modesto Leite (2019). Physicians are at a higher risk than the General Population for Suicide? Am. In. Mult. J., October a December. (7) 4, 189195.

Received: 11/25/2019

Accepted: 12/04/2019 